\title{
Some effects of vernalization on the reproductive capacity of Lolium perenne $\mathrm{L}$.
}

\section{A. Kleinendorst}

Institute for Biological and Chemical Research on Field Crops and Herbages (IBS), Wageningen, the Netherlands

Accepted: 1 November 1973

\section{Summary}

The vernalizing conditions affect the reproductive capacity of grasses (number of viable seeds produced).

A grass plant has to pass through various stages, in which certain requirements have to be met, before it starts seed formation. One of these stages is the vernalization period. Each tiller should be individually vernalized in order to form an inflorescence, in which the leaves (also those being initiated) are the perceptive organs. The length and the temperature during the vernalization period affect the ultimate number of spikelets formed. Also the carbohydrate content before and during vernalization affects this number. The number of spikelets, for instance, is greatly dependent on the length of the change-over period, which in its turn is affected by the conditions under which vernalization takes place.

A wide variation in reaction was found between the clones of perennial ryegrass with respect to the effect of vernalizing conditions.

\section{Introduction}

The reproductive capacity of grasses is determined by the number of viable seeds produced by one seed via the plant grown from it. To come to this stage of seed formation, however, the grass plant has to pass various other stages. Fig. 1 shows a schematic survey. To pass from one particular stage to another various requirements have to be met. Several external conditions are important in this, temperature and day-length being generally the most important.

After germination has taken place under favourable conditions, the plants enter the juvenile stage. Leaves are initiated and formed and lateral formation is started. The growing point as a rule has 2 to 3 vegetative primordia. In some species, such as Agrostis species (Cooper \& Calder, 1964), Festuca ovina L. (Wycherley, 1954), Lolium perenne L. (Cooper, 1951, 1960a), Poa pratensis L. (Peterson \& Loomis, 1949) and our winter cereals (Gott et al., 1955), certain external conditions can induce flowering already in the juvenile stage. In other species, such as Dactylis glomerata L. (Calder, 1963, 1964; Fedorov, 1958; Kozumplik \& Christie, 1972), Festuca pratensis Huds. (Bean, 1970; Fedorov, 1958) and maybe also in Phleum pratense L. (Ryle, 1963), the plants in the juvenile stage are not affected by these flower-inducing external conditions. Little is known about the nature of the factors determining the length of this period. 
It is assumed that the plant should have attained a minimum leaf area, or a certain number of leaves (Gregory, 1948; Holdsworth, 1956; Kozumplik \& Christie, 1972) or that the growing point should have a certain volume.

In the dicotyledonous species Lunaria biennis Moench, high light intensities can shorten the period of the insensitive juvenile stage (Wellensiek \& Higazy, 1961). This might indicate that the content of carbohydrates in the plant is important. It is not known whether each individual tiller in grasses shows an insensitive juvenile stage or whether this applies only to the entire plant.

The insensitive juvenile stage is followed by a stage in which the plants are indeed affected by flower-inducing or vernalizing external conditions. The species lacking the juvenile stage, of course, come into the vernalization stage immediately after germination.

Vernalizing conditions stimulate the plant to such an extent that it can react to the photoperiod-inducing flower initiation. In the literature this stage is frequently called the 'ripe to flower stage' (among others, by Calder, 1965). Vernalization takes place at low temperatures or in short day. To what extent short day can replace low temperatures in grasses and the reverse is not quite clear. The results with several grass species are rather deviating. Thus, Cooper \& Calder (1964) found that certain Bromus species were affected by low temperatures, but not by short day. It is known that in some cocksfoot types (Dactylis glomerata L.) a cold period can be replaced by short day and in tall fescue (Festuca arundinacea Schr.) the cold period is supposed to partly replace short day. According to Cooper (1952) the vernalized state would remain under conditions not favouring flower initiation. Purvis \& Gregory (1952) stated, however, that a high temperature immediately after or temporarily during the vernalization period could cause devernalization. Little is known about the biochemical changes taking place in the grasses during vernalization at low temperature or in short day (Evans, 1967).

When the plant is partly or completely vernalized, but the conditions (especially temperature and day-length) do not yet favour flower initiation, it is in the so-called transition stage. The limits of this stage are generally difficult to indicate exactly. When the temperature during this stage is sufficiently high, it is generally observed that the formation of primordia is more rapid than the formation and growth of new leaves. The length of the growing point increases as well as the number of primordia which are still vegetative.

However, as soon as the day-length increases sufficiently the plant changes to the reproductive stage. The growing point shows this by changing to the 'double ridge' stage; the leaf primordia do not further develop and new primordia are formed in the axils, which in continued reproductive development grow out to spikelets (spike) or branches of the inflorescene (panicle). Some grass species (e.g. Poa annua L.) are day neutral. In these species the initiation of inflorescences continues indepedent of daylength. Day neutral grasses are more or less an exception, as in by far the most grass species photoperiod is important in flower initiation. The day-length required for starting flower initiation varies widely between species, and even within species.

According to Evans (1960a, 1960b), who did much work with Lolium temulentum L., the leaf seems to be the most perceptive organ for the photoperiodic stimulance and also the place where a substance is formed which is translocated to the developing apex. It has become more and more likely that the pigment phytochrome is involved in the photoperiodic response (among others, Hendricks \& Borthwick, 1963).

However, it is not always photoperiod alone that determines flower initiation taking place or not; other external conditions may be important as well. Working with different 
varieties and origins of Poa, Hiesy (1953) demonstrated that in his material under an otherwise favourable day-length flowering occured at day temperatures of over $30^{\circ} \mathrm{C}$, provided night temperatures were kept below $10^{\circ} \mathrm{C}$. No flowering occurred at all when the night temperature remained above $17^{\circ} \mathrm{C}$, independent of the day temperature. These results agree with our own studies in which we found that no flowering occurred in smooth-stalked meadow grass (Poa pratensis L.), despite a favourable day-length, when the plants were placed and kept at $20^{\circ} \mathrm{C}$ before attaining the 'double-ridge' stage. Cooper (1960b) states that no flowering occurring at high night temperatures is a general phenomenon in grasses of the temperate areas. In the tropical short-day grasses, however, flower initiation seems to be stimulated by high night temperature (Evans, 1964).

Nutrition of the plants may also have a certain effect on flower initiation. Calder \& Cooper (1961) stated that in cocksfoot (Dactylis glomerata L.) flower initiation is clelayed or retarded by a low supply of nitrogen.

During the reproductive stage subsequently heading, flowering and seed setting take place, the stage coming to a close with the ripening of the seed. After this the relevant shoots die. During the reproductive stage the temperature is still important as well. Thus high temperatures, especially combined with a poor water supply, may cause substantial dying of the reproductive organs, after which fertilization will be poor and seed setting low.

During almost all the growth stages of a grass plant external conditions will affect one or more components of the seed yield, as number of fertile tillers, number of spikelets per ear, number of fertile flowers per spikelet and number of viable seeds (see Fig. 1).

This paper will be mainly limited to the vernalization period and the change-over to the purely reproductive stage in perennial ryegrass (Lolium perenne L.). In this species the length of the vernalization period may vary widely in individual plants. Among

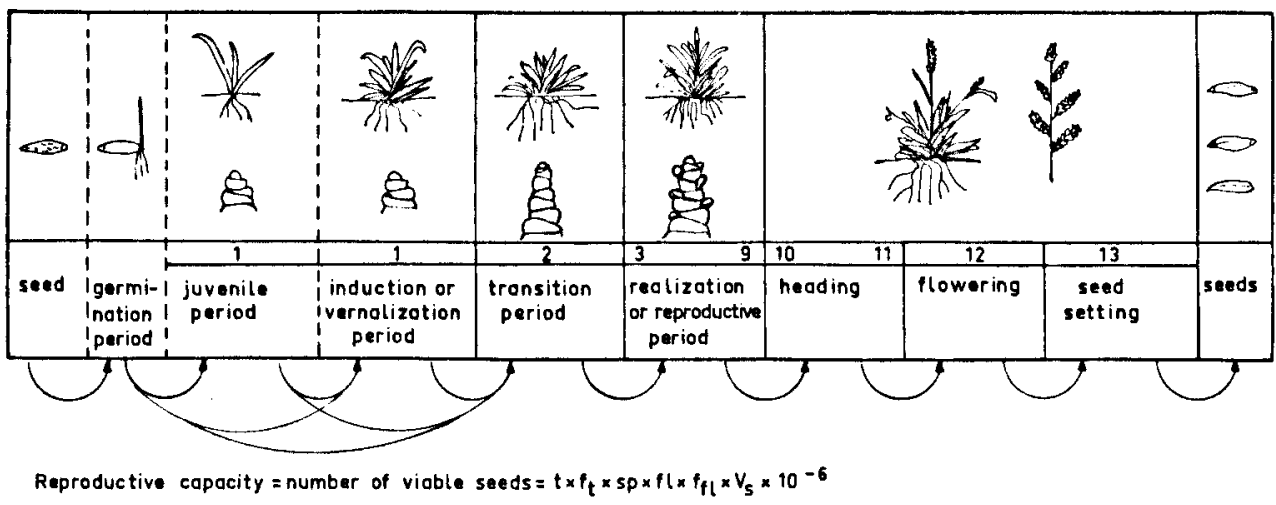

Fig. 1. Development stages of a grass plant from seed to seed. $t=$ number of tillers per plant; $\mathrm{f}_{\mathrm{t}}=$ percentage of fertile tillers per plant; $\mathrm{sp}=$ number of spikelets per ear; $\mathrm{fl}=$ number of flowers per spikelet; $f_{f 1}=$ percentage of fertile flowers (seed bearing) per spikelet; $V_{s}=$ percentage of viable seeds.

Figures indicate the development stages of the growing point (according to the development scale of Kleinendorst \& ten Hove, 1957). 
other things, it is affected by heritability, temperature, light conditions and carbohydrate reserves in the plant at the beginning of vernalization. Both during vernalization and curing the change-over to the reproductive stage these factors affect the various seed yield components. Thus, for instance, the number of spikelets per ear is largely determined by the conditions during the change-over.

\section{Some results of own research}

\section{Length of the vernalization period}

To obtain some idea about the moment at which the vernalization period outside under natural conditions is ended and about the length of the change-over period, plants were regularly brought inside during the winter and placed under conditions favourable to the plants to change over to the reproductive stage $\left(17\right.$ hours day-length at $\left.17^{\circ} \mathrm{C}\right)$. In Fig. 2 the number of days is plotted required from transference to the moment at which the inflorescences are visible. When the plants were brought inside at the end of November, only a few of these formed inflorescences, and as Fig. 2 shows (dotted lines) the number of days between transference and heading was rather great. Moreover, the few inflorescences formed showed considerable proliferation. In earlier work it was demonstrated that proliferation frequently occurs when vernalization has been incomplete (Kleinendorst \& Sonneveld, 1965a). After the beginning of January all the plants from commercial seed were heading already 40 days after transference. This number of days remained the same for all the plants transferred between the beginning of January and the end of March. This demonstrates that the plants from commercial seed under the conditions near Wageningen were already completely vernalized at the beginning of January in that particular winter. From then on they were in the changecver period which lasted till the end of March. At that time the outside conditions (day-length and temperature) were favourable for the plants to change over to the purely reproductive stage, starting with the formation of double ridges. After the beginning of March the number of days between transference and heading decreased continuously. An increasing part of reproductive development took place in the field.

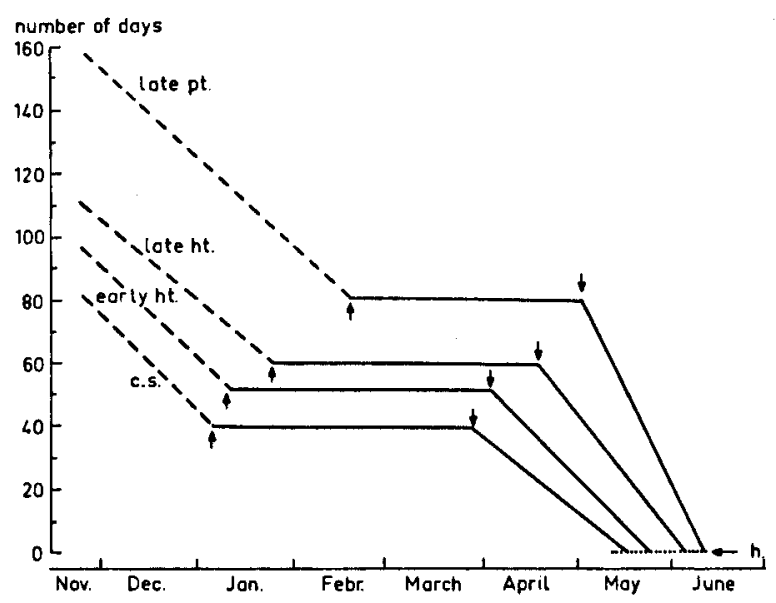

Fig. 2. Relation between date of transference to long day and number of days to heading of four types of perennial ryegrass.

c.s. = commercial seed; early ht. $=$ carly hay type, late ht. = late hay type, late pt. = late pasture type.

A moment at which the plants were completely vernalized outside;

$\downarrow$ moment at which the plants attained the 'double ridge' stage outside; $\leftarrow$ moment at which the plants were heading outside. 


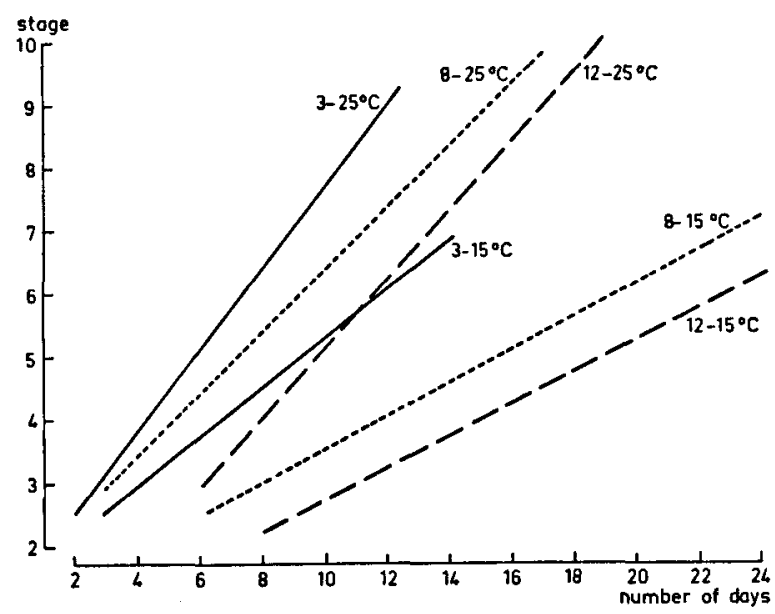

Fig. 3. Relation between number of days in long day and development of the growing point according to Fig. 1 (Kleinendorst \& ten Hove, 1957) of 3 different clones (3,8 and 12) of perennial ryegrass at $15^{\circ} \mathrm{C}$ and $25^{\circ} \mathrm{C}$.

In the other types of Lolium perenne studied, complete vernalization was attained later and paralleled lateness of heading in the field. Reproductive development in the field starting later caused the change-over period of the other types to be about equally long. With the eariy heading types, however, the change-over period in the field takes place in a period of lower temperature than with the late heading types.

Since the plants were transferred to $17^{\circ} \mathrm{C}$, the number of days under these conditions between transference and heading will be greater as the types are later heading in the field. Later heading types need a higher temperature to pass their reproductive development in the same time than early heading types.

Fig. 3 shows that generally higher temperature stimulates a more rapid passing of the reproductive development. However, a temperature rise has a greater effect as the plants head later in the field and requires a higher temperature. In Fig. 3 clone 3 is a very early heading one, while clone 12 heads very late (Kleinendorst \& Sonneveld, 1966).

The required length of the vernalization period can also be studied under artificial conditions by placing plants in conditioned greenhouses or climatic rooms. The advantage is that the investigation may continue throughout the year, because there is no need to wait for the winter period, and a better idea can be obtained about the conditions causing vernalization.

Plants of Lolium perenne placed at $2{ }^{\circ} \mathrm{C}$ in the dark for 1,2 and 3 months, respectively, were transferred to 17 hours of light at $20^{\circ} \mathrm{C}$. The number of days between transference and attaining the 'double ridge' stage and heading, respectively, is shown in Fig. 4. The number of days between attaining the 'double- ridge' stage and heading was not affected by the length of the period at low temperature. The number of days between transferring to long day and higher temperature and attaining the double ridge' stage however, was, considerably affected. After one or two months the plants were apparently not completely vernalized. Eventually they did form inflorescences, but after a longer change-over period. Table 1 shows that this had a fairly great influence on the composition of the inflorescences, especially on the number of spikelets per ear. This number increased with the longer duration of the change-over period. This will be referred to later in this paper. In this experiment a clone (No 3) was used, 


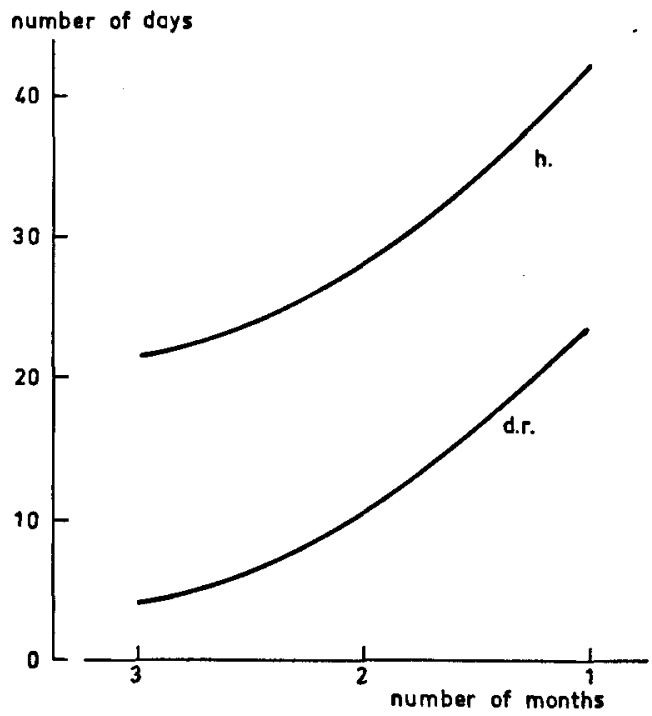

Fig. 4. Effect of vernalization period (months) on the number of days in long day to attaining the 'double ridge' stage (d.r.) and heading (h).

requiring a relatively short period at low temperature to be completely vernalized. After one month at $2{ }^{\circ} \mathrm{C}$ already $100 \%$ of the plants were heading (Table 1). Also in this respect there are great individual differences between the plants (clones). Fig. 5 gives an example of this. It concerns three clones of perennial ryegrass from the mountaineous region of Austria (collected by Sonneveld at an altitude of $1400 \mathrm{~m}$ ). In their habitat in Austria the three clones seemed to be strikingly uniform. Under the conditions near Wageningen their habits varied widely. At Wageningen in the field they headed rather early and at almost the same time. Under controlled conditions their cold requirement was found to vary widely. To obtain $100 \%$ of reproductive plants clone a only requires 12 weeks of vernalization; clone c, however, needs 18 weeks (Fig. 5a). Fig. $5 b$ shows that clones $a$ and $b$ are both completely vernalized after about 18 weeks (heading after 20 days); with clone complete vernalization takes about 3 weeks longer and this clone still needs about 5 days more to head (under the same controlled conditions as clones $a$ and $b$ ).

For complete vernalization not only the duration of the period is important, but also the temperature and light conditions. The results of studying three clones of L. perenne from various parts of the Netherlands have been summarized in Fig 6 . These clones were vernalized at 2 and $6{ }^{\circ} \mathrm{C}$ in 8 hours of artificial light or in continuous darkness.

Table 1. Average percentage of heading plants and other data on the ear formation of these plants.

\begin{tabular}{llllll}
\hline $\begin{array}{l}\text { Vernalization } \\
\text { period }\end{array}$ & $\begin{array}{l}\text { Heading } \\
\text { plants (\%) }\end{array}$ & $\begin{array}{l}\text { Days to } \\
\text { heading }\end{array}$ & $\begin{array}{l}\text { Spikelets } \\
\text { per ear }\end{array}$ & $\begin{array}{l}\text { Flowers per } \\
\text { spikelet }\end{array}$ & $\begin{array}{l}\text { Length of } \\
\text { ear (cm) }\end{array}$ \\
1 month & 100 & 42 & 24.3 & 7.1 & 24.8 \\
2 months & 96 & 28 & 19.4 & 8.3 & 23.6 \\
3 months & 100 & 22 & 16.4 & 8.3 & 21.2 \\
\hline
\end{tabular}




\section{A. KLEINENDORST}

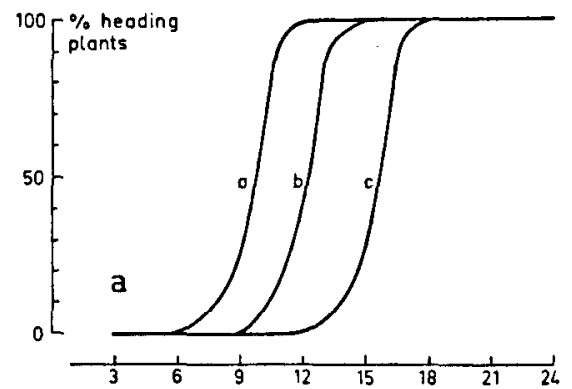

Fig. 5. a. Relation between vernalization period (weeks) and the percentage of heading in 3 clones of perennial ryegrass; b. Relation between vernalization period and number of days in long day and higher temperature to heading of the same clones.
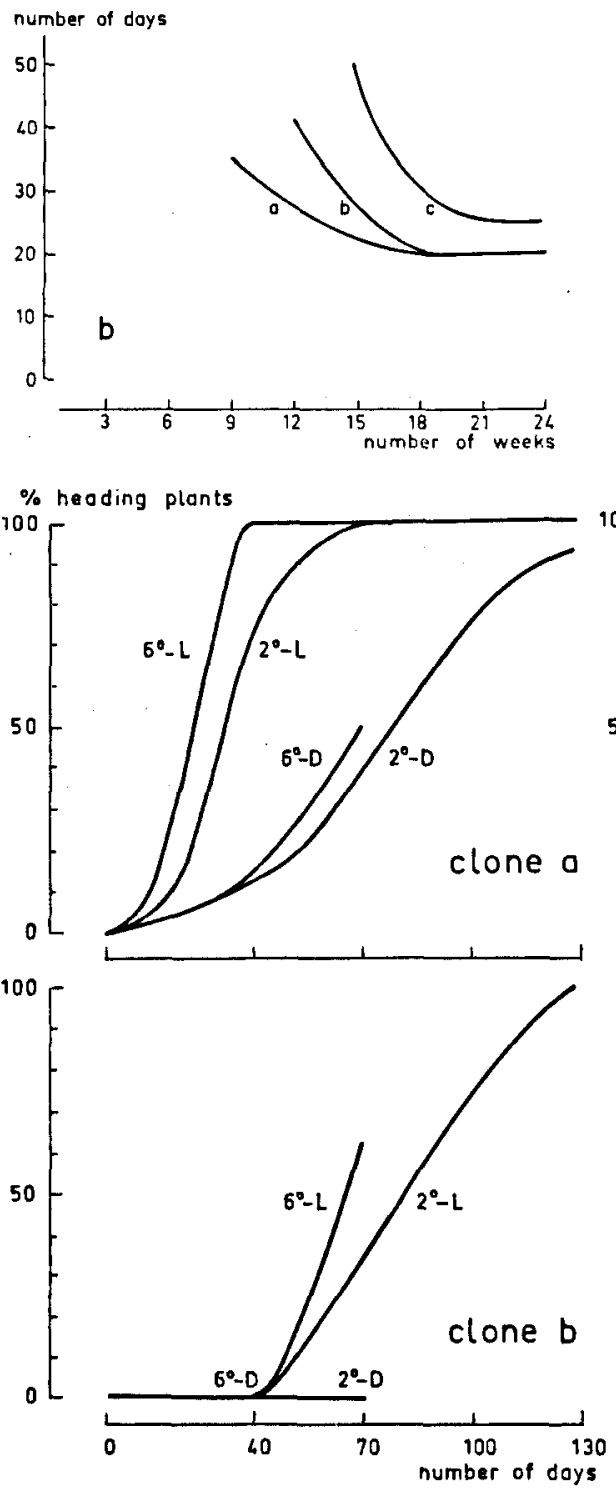

$\%$ heading plants

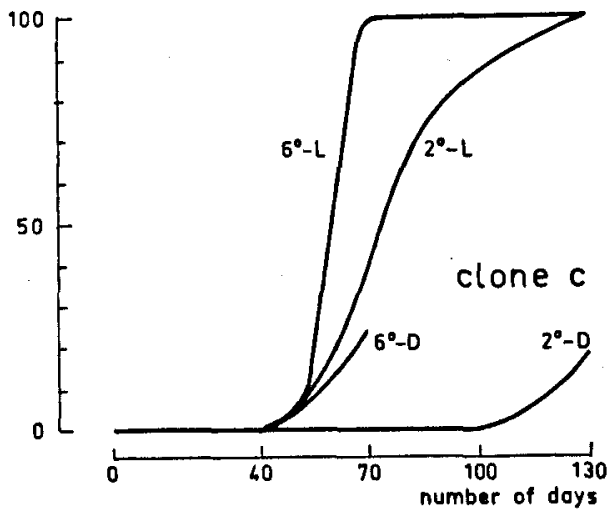

Fig. 6. Relation between vernalization period (days) and percentage of headed plants in 3 clones of perennial ryegrass, vernalized at $2^{\circ} \mathrm{C}$ and $6^{\circ} \mathrm{C}$ in the light (L) and in darkness (D). 
With all three clones a temperature of $6^{\circ} \mathrm{C}$ and 8 hours of light gave the most rapid vernalization. Yet there were wide differences between the clones. Vernalization at $6{ }^{\circ} \mathrm{C}$ in the light gave indeed in clone b a number of reproductive plants, but $100 \%$ was not attained, because the plants died after 70 days under these vernalizing conditions. The same occurred in clones $a$ and $c$ when the plants remained in complete darkness at $6^{\circ} \mathrm{C}$ longer than 70 days. In clone $\mathrm{c}$ many plants died after 130 days in darkness at $2{ }^{\circ} \mathrm{C}$. Under the same conditions this only happened with a few plants of clone a.

Vernalization in darkness was completely impossible for clone b. At $2^{\circ} \mathrm{C}$ as well as at $6^{\circ} \mathrm{C}$ all the plants died after 70 and 40 days, respectively.

The carbohydrate content before and during vernalization

The question arises what may be the reason of these differences between clones. Different levels of carbohydrate reserves within the plants may be important. To obtain more information about this, a number of plants were grown of the same clone, but with a high or a low level of carbohydrate reserves. This was done by growing the plants at a relatively low temperature with a low $\mathrm{N}$ level under high light intensity or at a relatively high temperature with a high $\mathrm{N}$ level under low light intensity. Both groups of plants were placed at $2{ }^{\circ} \mathrm{C}$ in the dark for vernalization. After 2 months the plants were placed under conditions of long day and $20^{\circ} \mathrm{C}$ on water culture with or without nitrogen. Table 2 shows that the carbohydrate level greatly affected the number of plants producing inflorescences. When no nitrogen was supplied after complete vernalization, no inflorescences were formed ( $C$ and $D$ ). In the plants poor in total soluble carbohydrates (TSC) this could not be reversed by supplying nitrogen after 57 days (G). Of the plants rich in TSC, however, about half still produced inflorescences when supplied with nitrogen 50 days after complete vernalization $(H)$. Plants receiving $N$ after vernalization formed inflorescences, also when the $\mathrm{N}$ supply was stopped after attaining the doubleridge' stage (A, B and E, F, respectively). However, also in these plants the TSC level before vernalization greatly affected the number of inflorescences formed.

For the next experiment plants of the same clone were again grown with a high or a low carbohydrate reserve. Now both groups of plants were placed at $2{ }^{\circ} \mathrm{C}$ and $6{ }^{\circ} \mathrm{C}$ either in complete darkness or in 8 hours of artificial light per day. After 1, 2 and 3 months a number of plants were harvested and analysed for carbohydrate level.

Table 2. Level of total soluble carbohydrates (TSC) before vernalization, $\mathrm{N}$ application during the long day treatment and percentage of reproductive plants under conditions of long day and $20^{\circ} \mathrm{C}$.

\begin{tabular}{llll}
\hline $\begin{array}{l}\text { Category of } \\
\text { plants }\end{array}$ & $\begin{array}{l}\text { TSC before } \\
\text { vernalization }\end{array}$ & $\begin{array}{l}\text { N application } \\
\text { during the } \\
\text { long day } \\
\text { treatment }\end{array}$ & $\begin{array}{l}\text { Plants } \\
\text { producing } \\
\text { inflorescences (\%) }\end{array}$ \\
A & low & $+N$ & 4 \\
B & high & $+N$ & 90 \\
C & low & $-N$ & 0 \\
D & high & $-N$ & 4 \\
E & low & +N, after d.r.1 -N & 4 \\
F & high & +N, after d.r. -N & 71 \\
G & low & -N, after 57 days +N & 0 \\
H & high & -N, after 50 days +N & 46 \\
\hline
\end{tabular}

d.r. = 'double ridge' stage. 

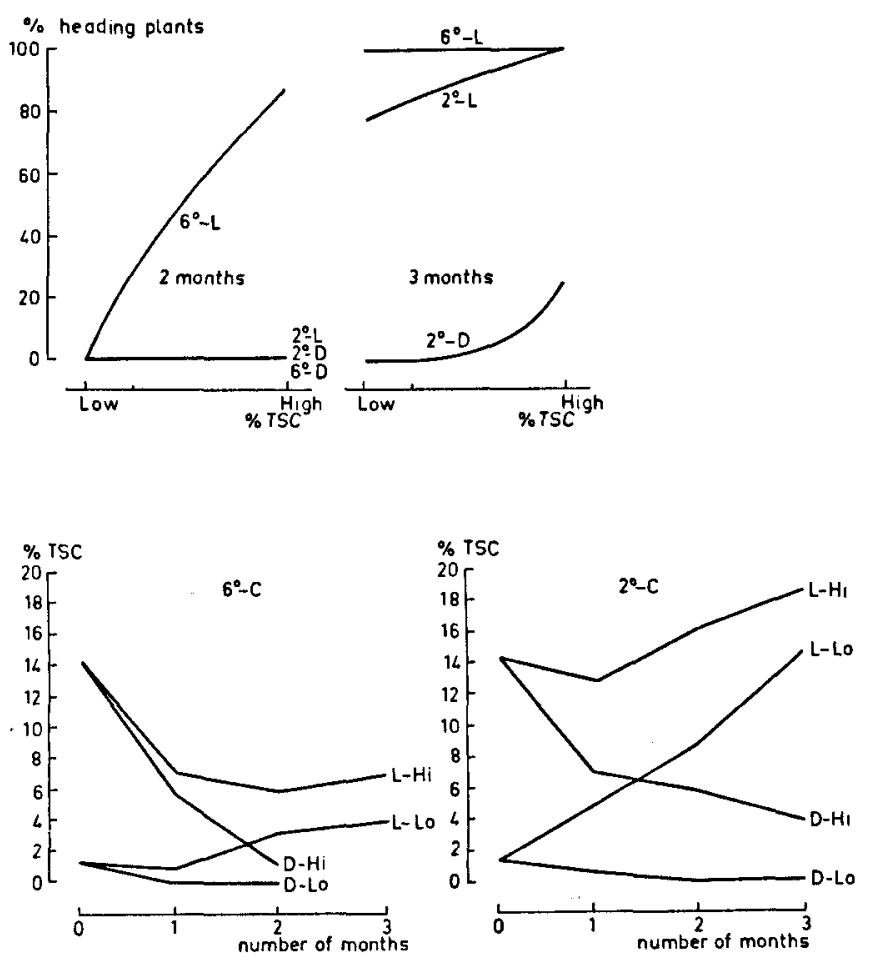

Fig. 7. Top: effect of high and low level of total soluble carbohydrates before vernalization on the percentage of heading plants after 2 and 3 months vernalization at $2^{\circ} \mathrm{C}$ and $6{ }^{\circ} \mathrm{C}$ in the light (L) and in darkness (D).

Bottom: trend in the percentage of total soluble carbohydrates (TSC) in the above-ground parts of plants with a high (Hi) and a low (Lo) content before vernalization at $6{ }^{\circ} \mathrm{C}$ and $2{ }^{\circ} \mathrm{C}$ in the light (L) and in darkness (D).

Fig. 7 (bottom) shows that the carbohydrate level in the plants under vernalizing conditions is greatly affected by temperature and light conditions. At $2^{\circ} \mathrm{C}$ the carbohydrate content during darkness decreased distinctly, in 8 hours of light per day it clearly increased. At $6^{\circ} \mathrm{C}$ in darkness the carbohydrate content decreased to such an extent that after two months an extremely low level was attained, and these plants accordingly died when they were transferred to long day at $20^{\circ} \mathrm{C}$. Respiration at $6{ }^{\circ} \mathrm{C}$ was already so much higher than at $2{ }^{\circ} \mathrm{C}$ that the amount of light supplied hardly could raise the carbohydrate content. Only in the plants which were transferred to vernalizing conditions with a low carbohydrate content this level could still rise somewhat. At $6{ }^{\circ} \mathrm{C}$ respiration was not only higher, but the plants also showed some growth.

Fig. 7 (top) shows that after 2 months under vernalizing conditions only the plants rich in TSC in the light at $6{ }^{\circ} \mathrm{C}$ were vernalized sufficiently to form nearly all an infiorescence under favourable conditions. Of the plants poor in TSC under these vernalizing conditions none was able to form inflorescences.

After three months of vernalization there was no difference anymore whether plants with a high level or with a low level were placed in 8 hours of light at $6^{\circ} \mathrm{C}$. All the plants formed inflorescences. At $2{ }^{\circ} \mathrm{C}$ it still showed some effect. At that temperature 


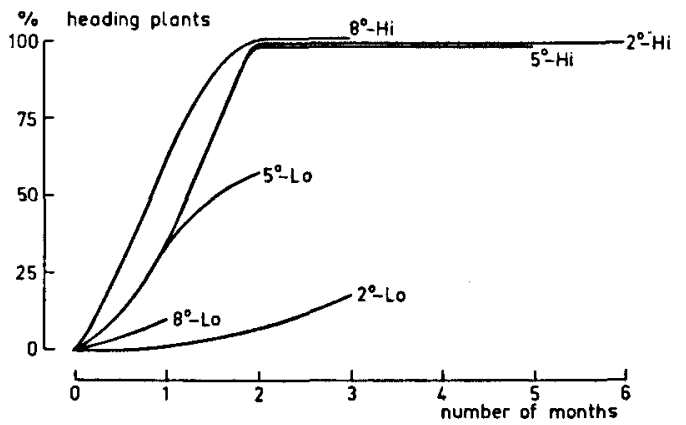

Fig. 8. Effect of vernalization period (months) at 2,5 and $8^{\circ} \mathrm{C}$ on the percentage of heading plants. Plants before vernalization with high (Hi) or low (Lo) TSC content.

not all the plants poor in TSC formed inflorescences. The plants in the dark at $6{ }^{\circ} \mathrm{C}$ were already dead after three months, at $2^{\circ} \mathrm{C}$ only a small number of the plants rich in TSC formed inflorescences. These results indicate that the level of carbohydrate reserves within the plants indeed greatly affect the vernalization process.

This conclusion was confirmed by an experiment in which plants with a high and with a low level of carbohydrate reserves were vernalized in the dark at 2,5 and $8{ }^{\circ} \mathrm{C}$, respectively (Fig. 8). The plants rich in TSC all formed inflorescences after two months of vernalization. After one month of vernalization the plants at $8{ }^{\circ} \mathrm{C}$ showed a slight advantage. After six months at $2{ }^{\circ} \mathrm{C}$ all the plants were still alive, the plants at $5{ }^{\circ} \mathrm{C}$ all being dead by that time. This occurred already after four months with the plants at $8^{\circ} \mathrm{C}$.

The situation of the plants subjected to the vernalizing conditions with a low level of carbohydrate reserves was completely different. After one month of vernalization the plants at $5^{\circ} \mathrm{C}$ showed a distinct advantage with respect to inflorescence formation. After two months all the plants at $8{ }^{\circ} \mathrm{C}$ were dead, after three months all those at $5{ }^{\circ} \mathrm{C}$ and after four months even those at $2^{\circ} \mathrm{C}$.

It is difficult to suggest the best absolute level of carbohydrate reserves. Under equal external conditions the TSC content may vary widely from plant to plant and from clone to clone, which is illustrated by Table 3 . These data were obtained by growing the plants of four clones in a conditioned room for some time under 'normal' conditions (A), under conditions stimulating accumulation of reserves (B) and under conditions stimulating a considerable use of the reserves $(\mathrm{C})$. The level of carbohydrate reserves in the four clones varied considerably, also under the extreme conditions. It was also found that plants of clone 16 were still alive with a TSC content of about $1 \%$, while

Table 3. The TSC-content of four clones of Lolium perenne L., grown under three very different complexes of external conditions (see text).

\begin{tabular}{lllc}
\hline Clone No & $\begin{array}{l}\text { 'Normal' TSC } \\
\text { (A) }\end{array}$ & $\begin{array}{l}\text { High TSC } \\
\text { (B) }\end{array}$ & $\begin{array}{l}\text { Low TSC } \\
\text { (C) }\end{array}$ \\
3 & 17.2 & 38.0 & 6.9 \\
12 & 26.6 & 40.1 & 13.6 \\
16 & 5.3 & 23.0 & 1.6 \\
21 & 25.9 & 44.7 & 16.2 \\
\hline
\end{tabular}


plants of clone 12 already died with a TSC content dropping just below $10 \%$.

These data will make it clear that no suggestion can be made as to which conditions are in general favourable for rapid and optimum vernalization. The optimum conditions vary widely and depend, among other things, on the hereditary characters of the plants concerned, the level of the carbohydrate reserves and light conditions during vernalization.

In the introduction species were already mentioned with an insensitive juvenile stage for vernalization, and it was also supposed that the carbohydrate reserves might be an imporiant factor in this. The experimental data mentioned make this suggestion more likely. However, the question remains whether these are species with low carbohydrate reserves in their juvenile stages or whether these are species with a high requirement of their carbohydrate reserves for vernalization.

\section{Translocation of vernalization}

There is a controversy in the literature on the question whether the whole plant shruld be subjected to the vernalizing conditions, or whether only certain parts should be subjected. Many workers consider that especially parts with intensive cell divisions are concerned (Calder, 1965). This does not apply, in any case, to the species with an intensitive juvenile stage, in which many dividing tissues are present. Others state that the apex itself should be subjected to the vernalizing conditions, with a second requirement of the apex having a certain volume.

With a specially developed set-up roots, growing points and leaves of a clone of $L$. were separately subjected to various temperatures (Kleinendorst, 1969). The different temperature combinations applied have been summarized in Table 4. After two months under these temperature conditions, only those plants formed inflorescences under favourable conditions that had received a leaf temperature of $6^{\circ} \mathrm{C}$ in their combinations. This indicates that at least in the clone used, the leaves were the recipient organs.

Also in perennial grass species vernalization should take place every year. The vernalized condition clearly does not continue in the plant. A vernalized tiller, however, can maintain its vernalized condition for a reasonably long period when the conditions are not favourable for a change-over to the reproductive stage (Cooper, 1952). The vernalized condition, however, is supposed to be affected by high temperatures, especially immediately after vernalization and when this was not done optimally (Purvis \& Gregory, 1952).

There is considerable controversy whether the vernalized condition can be trans-

Table 4. Temperature combinations applied to the leaf, growing point and root mediums (see text).

\begin{tabular}{lcc}
\hline Temperature $\left({ }^{\circ} \mathrm{C}\right)$ of & \\
\hline leaves & growing points & roots \\
6 & 6 & 6 \\
6 & 6 & 16 \\
6 & 16 & 16 \\
16 & 16 & 16 \\
16 & 16 & 6 \\
16 & 6 & 6 \\
\hline
\end{tabular}



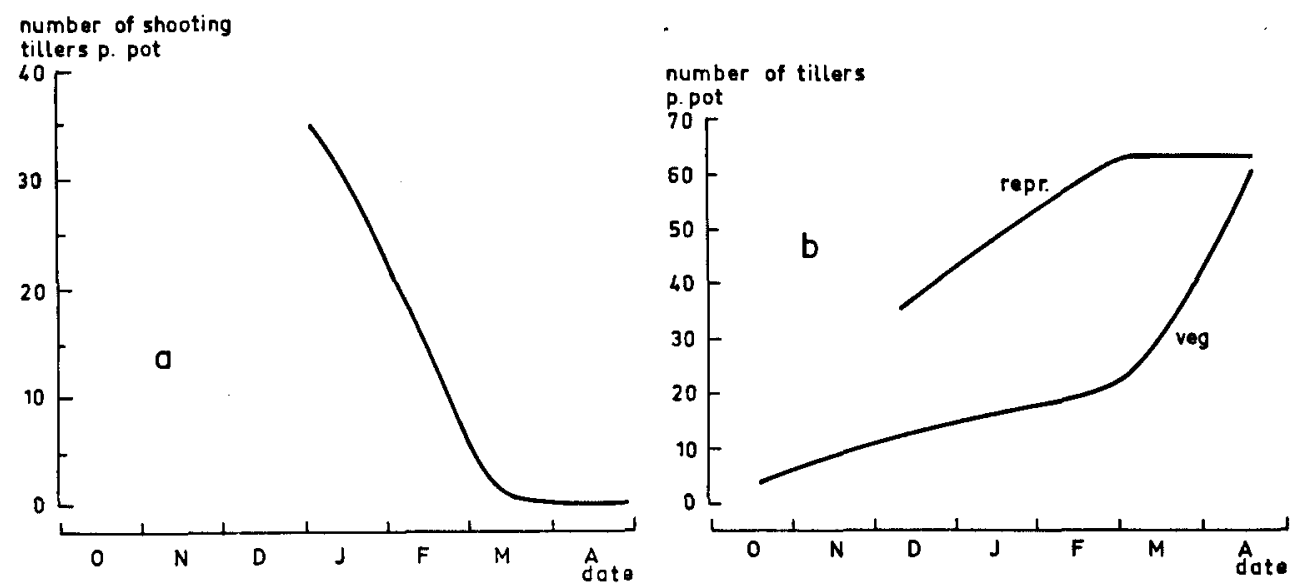

Fig. 9. a. Trend in the number of shooting tillers of plants transferred during winter (January till April) from a greenhouse (in long day) outside (natural day-length and temperature).

b. Trend in the number of vegetative tillers under natural conditions from October to April (veg). The 'repr,' line indicates the number of shooting tillers of plants placed in a greenhouse (in long day) during the period from the beginning of December to the end of April

located to subsequent generations of tillers (Calder, 1965). The following experiments suggest prevailingly that each individual tiller should be vernalized in order to form an inflorescence.

On 19 October a great number of pots was planted each with four separate tillers of a $L$. clone and placed outside. From half December until the end of April some pots were regularly brought inside and placed under conditions favourable to inflorescence formation. In Fig. 9, line b-veg. shows the number of visible tillers per pot outside. The number increased to some extent during winter; after the beginning of March, l:owever, it increased very rapidly. Line b-repr. shows the number of tillers per pot producing an inflorescence, which is plotted against the date when pots were brought in the greenhouse. Until the beginning of March this is about three times that of the tillers visible at the moment of transference. Dissecting tillers one always finds at least two or three small ones developing in the leaf axils, which are invisible outside. Therefore the number of tillers producing an inflorescence is about the same as the total number of tillers, large, small, or even very small, present at the moment of transference.

Transference in March did not yield more inflorescences. Therefore, the tillers formed some time before this date were not vernalized. This is in agreement with the results obtained in the reverse experiments (Fig. 9a). Pots planted at the same time with the same clone were kept inside, and from the beginning of January some of them were regularly brought outside. The later the pots were transferred, the smaller the number of inflorescences produced and the pots brought outside after the beginning of March did not produce inflorescences at all.

These results were confirmed by another experiment in which, at the end of the vernalization period, plants were divided into main tillers and visible lateral tillers of the first, second, third and fourth order. All these tillers were planted separately and were placed under conditions favourable to inflorescence formation. Table 5 shows that the older the tiller and, therefore, the higher the number of leaves present on it, the 
Table 5. Influence of the vernalization on separate main tillers and laterals.

\begin{tabular}{|c|c|c|c|c|c|}
\hline & \multirow{2}{*}{$\begin{array}{l}\text { Tillers } \\
\text { after } \\
\text { vernalization }\end{array}$} & \multirow{2}{*}{$\begin{array}{l}\text { Shooting } \\
\text { tillers }\end{array}$} & \multirow{2}{*}{$\begin{array}{l}\text { Vegetative } \\
\text { tillers }\end{array}$} & \multicolumn{2}{|c|}{ Heading date } \\
\hline & & & & $\begin{array}{l}\text { main } \\
\text { tillers }\end{array}$ & laterals \\
\hline Main tiller & 1.0 & 3.2 & 28 & $26 / 4$ & $6 / 5$ \\
\hline 1st lateral & 1.0 & 3.7 & 24 & $21 / 4$ & $5 / 5$ \\
\hline 2nd lateral & 1.0 & 2.3 & 29 & $22 / 4$ & $10 / 5$ \\
\hline 3 th lateral & 1.0 & 1.7 & 33 & $26 / 4$ & $13 / 5$ \\
\hline 4th lateral & 1.0 & 1.0 & 24 & $30 / 4$ & - \\
\hline
\end{tabular}

greater the number of inflorescences formed. This corresponds with the greater number of small invisible lateral tillers present on the tillers with more leaves.

All these experiments suggest that there is no translocation of vernalization. What may have been interpreted as such, actually seems vernalization of present, but as yet invisible tillers.

\section{Composition of the inflorescence}

In Table 1 a relation was already demonstrated between the length of the vernalization period and composition of the inflorescences formed afterwards. It was also pointed out that the length of the period between sufficient vernalization and change-over to the 'double ridge' stage was important in this respect.

There is a close relation between the number of vegetative primordia on the apex at the time of the change-over to the 'double ridge' stage and the ultimate number of spikelets in the ear (Kleinendorst \& ten Hove, 1957; Ryle \& Langer, 1963; Kleinendorst \& Sonneveld, 1965b, 1966), which is illustrated in Fig. 10. The data come from an experiment in which plants from the same clone of $L$. perenne after some variations in vernalization were placed under a day-length of 17 hours at $15^{\circ} \mathrm{C}$ and $25^{\circ} \mathrm{C}$,

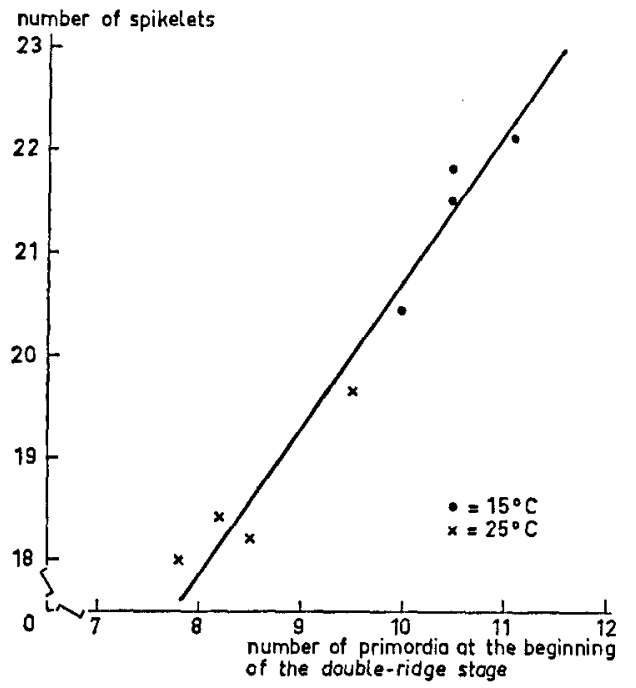

Fig. 10. Relation between number of primordia at the moment of change-over to the reproductive stage ('double ridge') and the ultimate spikelet number per ear (Kleinendorst \& Sonneveld. 1966). 


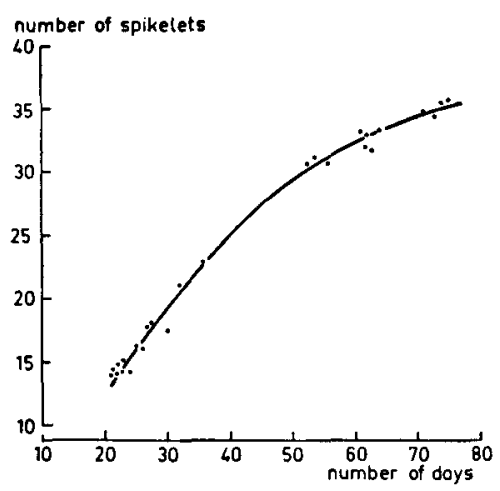

respectively. At $15^{\circ} \mathrm{C}$ the period between transference and attaining the 'double ridge' stage was longer than at $25^{\circ} \mathrm{C}$. This resulted in more vegetative primordia on a more elongated apex at the time of change-over to the reproductive stage ('double ridge'), which resulted in a greater ultimate number of spikelets per ear. Length of the changeover period as well as temperature are important. In the data of Fig. 10 the longer change-over period was decisive. At equal length of the change-over period the number of vegetative primordia is positively affected by higher temperatures. Therefore, the ultimate number of spikelets per ear of late flowering types, which have their changeover periods at higher temperatures is higher than that of early flowering types (cf. Fig. 2).

Fig. 11 summarizes the results of an experiment in which plants of the same clone were kept under very different conditions before and during the period of vernalization. This resulted in great differences in the number of days between transference to favourable heading conditions and the actual date of heading. There was no difference in the length of the period between attaining the 'double ridge' stage and date of heading. Fig. 11 clearly demonstrates the effect of the length of the change-over period on the ultimate spikelet number per ear.

When research on grass seed production in the Netherlands started the opinion was that the seed production potential of the early flowering types was greater than that of the late flowering ones. Sonneveld \& Evers (1955), making many ear analyses, however showed that this was certainly not true. In general the average number of spikelets per ear was greater with the late flowering types. This is in agreement with the above mentioned results of experiments. The actual seed yield in weight of the late flowering types, however, tends to be smaller, because of the smaller number of fullgrown seeds per spikelet and the smaller or even much smaller size of each individual seed.

Very interesting in respect to the problem are the results of Hertzsch et al. (1964), who planted a number of very early to very late flowering types of $L$. perenne at three different latitudes. Fig. 12a shows the number of days between the start of the vegetative growth in spring and the date of heading. At our latitude $\left(51^{\circ} \mathrm{N}\right)$ this period varied widely. At higher latitudes the differences were much smaller. This means that the differences in the length of the period between sufficient vernalization and reaching the 'double ridge' stage must also be much smaller and that will be reflected in the number of spikelets per ear. As can be seen from Fig. 12b this was indeed found.

Neth. J. agric. Sci. 22 (1974) 


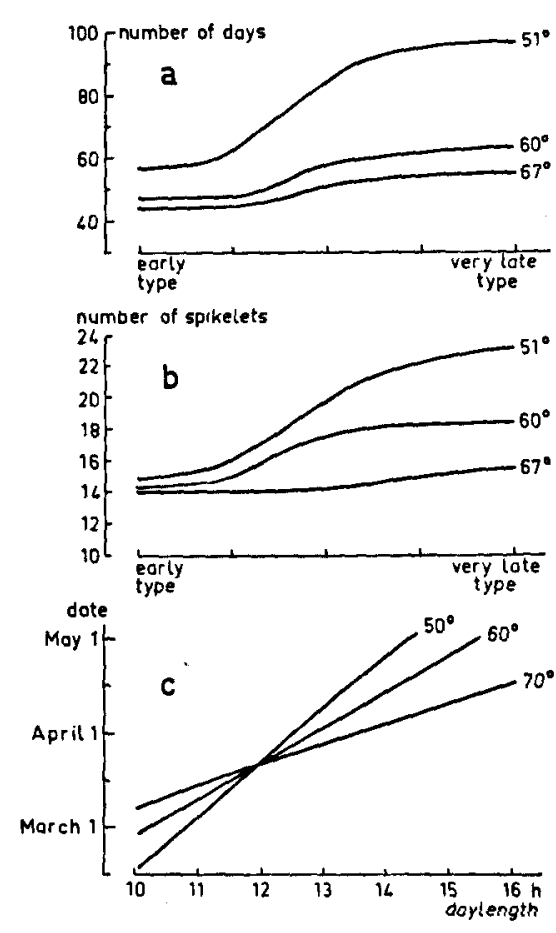

Fig. 12. a. Relation between early to very late types of perennial ryegrass and number of days to heading at 3 latitudes.

b. Relation between early to very late types and the number of ultimate spikelets per ear at 3 latitudes.

c. Trend in the day length at 3 latitudes (Hertzsch et al., 1964).

When day-length is plotted against date (Fig. 12c) it is clear that a certain day length needed to start the 'double ridge' stage (e.g. 141/2 hours) is attained earlier at the higher latitudes than at our latitude. In the mean time also the temperature will have grown higher. All this has the interesting effect that our early heading types have about the same number of spikelets per ear at different latitudes. Our late heading types, however, have a greater number of spikelets at our latitude, but about the same number as the early heading ones at much higher latitudes.

Insufficient knowledge of the above mentioned effects has led to much confusion in the literature in relation to the interpretation of experimental results.

\section{Acknowledgment}

I am indebted to Ir A. Sonneveld for his he:pful advice and criticism during the experimental work and in the preparation of the manuscript and to miss A. H. van Rossem for translating the manuscript.

\section{Keferences}

Bean, E. W., 1970. Short-day and low-temperature control of floral induction in Festuca. Ann. Bot. 34: 57-66.

Calder, D. M., 1963. Environmental control of flowering in Dactylis glomerata L. Nature, Lond. 197: 882-883.

Calder, D. M., 1964. Stage development and flowering in Dactylis glomerata L. Ann. Bot. 28: 187-206.

Calder, D. M., 1965. Inflorescence induction and initiation in the Gramineae. The growth of cereals and grasses. Proc. Easter School agric, Sci. Nott. 12: 59-73. 
Calder, D. M., \& J. P. Cooper, 1961. Effect of spacing and nitrogen level on floral initiation in cocksfoot. Nature, Lond. 191: 195-196.

Cooper, J. P., 1951. Studies on growth and development in Lolium. 2. Pattern of bud development of the shoot apex and its ecological significance. J. Ecol. 39: 228-270.

Cooper, J. P., 1952. Studies on growth and development in Lolium. 3. Influence of season and latitude on ear-emergence. J. Ecol. 40: 352-379.

Cooper, J. P., 1960a. Short-day and low-temperature induction in Lolium. Ann. Bot. 24: 232-246.

Cooper, J. P., 1960b. The use of controlled life-cycles in the forage grasses and legumes. Herb. Abstr. 30: 71-79.

Cooper, J. P. \& D. M. Calder, 1964. The inductive requirements for flowering of some temperate grasses. J. Br. Grassl. Soc. 19: 6-14.

Evans, L. T., 1960a. Inflorescence initiation in Lolium temulentum L. I. Effect of plant age and leaf area on sensitivity to photoperiodic induction. Aust. J. biol. Sci. 13: 123-131.

Evans, L. T., 1960b. Inflorescence initiation in Lolium temulentum L. II. Evidence for inhibitory and promotive photoperiodic processes involving transmissible products. Aust. J. biol. Sci. 13: $429-440$

Evans, L. T., 1964. In: Grasses and grasslands. London, Macmillan.

Evans, L. T., 1967. Cellular and molecular aspects of floral induction. Proc. Symp. Liège, Belgium. Fedorov, A. K., 1958. Phasenentwicklung bei perennierenden Futtergräsern. Agrobiologiya 5: 57-59.

Gott, M. B., F. G. Gregory \& O. N. Purvis, 1955. Studies in vernalization of cereals. XIII. Photoperiodic control of stages in flowering between initiation and ear formation vernalised and unvernalised Petkus winterrye. Ann, Bot. 19: 87-126.

Gregory, F. G., 1948. The control of flowering in plants. Symp. Soc, exp. Biol. 2: 75-103.

Hendricks, S. B. \& H. A. Borthwick, 1963. In: Environmental control of plant growth. London, Academic Press.

Hertzsch, W., W. Nitzsche, O. Valle \& K. Bergt, 1964. Schosserbildung von Lolium perenne beim Anbau an Orten verschiedener geographischer Breite. Z. PflZücht. 51: 347-353.

Hiesey, W. M., 1953. Growth and development of species and hybrids of Poa under controlled temperatures. Am. J. Bot. 40: 205-221.

Holdsworth, M., 1956. The concept of minimum leaf number. J. exp. Bot. 7: 395-409.

Kleinendorst, A., 1969. The effect of low temperature around shoot, growing point and root on the vernalization of Lolium perenne. Jaarb. Inst. biol. scheik. Onderz. Landb. Gewassen. 1969: 11-18.

Kleinendorst, A. \& H. J. ten Hove, 1957. Onderzoek aan het groeipunt bij enkele grassen. Jaarb. Inst. biol. scheik. Onderz. Landb. Gewassen. 1957: 39-49.

Kleinendorst, A. \& A. Sonneveld, 1965a. Influence of the number of days in continuous light, after vernalization, on shooting and morphology of the inflorescences of two types of perennial ryegrass. Jaarb. Inst. biol. scheik. Onderz. Landb. Gewassen. 1965: 41-48.

Kleinendorst, A. \& A. Sonneveld, 1965b. Influence of the vernalization period and light intensity on shooting and composition of the inflorescence of perennial ryegrass. Jaarb. Inst. biol. scheik. Onderz. Landb. Gewassen. 1965: 49-55.

Kleinendorst, A. \& A. Sonneveld, 1966. Influence of light intensity and temperature before and after attaining the reproductive phase on the behaviour of perennial ryegrass. Jaarb. Inst. biol. scheik. Onderz. Landb. Gewassen. 1966: 19-29.

Kozumplik, V. \& B. R. Christie, 1972. Completion of the juvenile stage in orchard grass. Can. J. Pl. Sci. 52: 203-208

Peterson, M. L. \& W. E. Loomis, 1949. Effects of photoperiod and temperature on growth and flowering of Kentucky blue grass. Pl. Physiol. 24: 31-43.

Purvis, O. N. \& F. G. Gregory, 1952. Studies in vernalization. XII. The reversibility by high temperature of the vernalized condition in Petkus winter rye, Ann. Bot. 16: 1-21.

Ryle, G. J. A., 1963. Studies on the physiology of flowering of timothy. III. Effects of shoot age and nitrogen level on the timing of inflorescence production. Ann. Bot. 27: 453-465.

Ryle, G. J. A. \& R. H. M. Langer, 1963. Studies on the physiology of flowering of timothy. I. Influence of daylength and temperature on initiation and differentiation of the inflorescence. Ann. Bot. 27: 213-229.

Sonneveld, A. \& A. Evers, 1955. Hebben de laat bloeiende en sterk stoelende typen van onze weidegrassen een geringere neiging tot generatieve voortplanting. Versl. Centr. Inst. landbouwk. Onderz. 1954: 101-108.

Wellensiek, S. J. \& M. H. Higazy, 1961. The juvenile phase for flowering in Lunaria biennis. Proc. Kon. Ned. Akad. Wet. C 64: 458-463.

Wycherley, P. R., 1954. Vegetative proliferations of floral spikelets in British grasses, Ann. Bot. 18: $119-127$. 